\title{
Psychometric evaluation of recall and recognition tasks for the measurement of young spectators' theatrical memory
}

\author{
Evaluación psicométrica del recuerdo y el reconocimiento de \\ tareas para la medida de la memoria teatral de jóvenes \\ espectadores
}

\section{Avaluació psicomètrica del record i el reconeixement de tasques per a la mesura de la memòria teatral de joves espectadors}

\author{
Alexia Papakosta. National and Kapodistrian University of Athens, Department of Primary \\ Education, Greece. alexpa@primedu.uoa.gr \\ https://orcid.org/0000-0003-2613-005X
}

Konstantinos Mastrothanasis. University of the Aegean, Department of Primary

Education, Greece. pred18001@aegean.gr

http://orcid.org/0000-0002-8703-9607

Aphrodite Andreou. National and Kapodistrian University of Athens, Department of Primary Education, Greece. andreouaphr@primedu.uoa.gr

https://orcid.org/0000-0002-2730-9329

Ioanna Blouti. National and Kapodistrian University of Athens, Department of Primary Education, Greece. ioanna.blouti@gmail.com

https://orcid.org/0000-0002-2405-2273

\begin{abstract}
The purpose of this research is the construction and psychometric evaluation of seven categories of recall and recognition tasks for the measurement of young spectators' theatrical memory, based on the respective theatre codes of a specific performance for young audiences. The aim of those tasks is the evaluation of the young spectators' mnemonic recordings on a level of a) the actors' representation of the characters on stage (acting), b) the visual frame of the performance, c) the audio code, d) the lights, e) the dramatic text, f) the plot/action and g) the Shadow Theatre technique.

The recall and recognition tasks were constructed according to the Classical Test Theory of Question Analysis on a sample of 5th Grade Primary School pupils, who had seen this specific performance addressed to young spectators and were evaluated with the Factor Analysis method. For the evaluation of the quality of the questions, we took into consideration the difficulty coefficient of each question, the discriminant coefficient and the evaluation of the correlation level of expert
\end{abstract}


judges. For the psychometric control of the tests we examined the validity of their conceptual construction via inquiry factor analysis and the internal validity coefficient.

The result of the above tasks was the creation of seven reliable and valid measurement tools, in which no gender effect is inferred.

Key words: Classical Test Theory of Question Analysis, Theatrical Memory, Young Spectators, Recall Tasks, Recognition Tasks, Psychometric Evaluation.

\section{Resumen}

El objetivo de esta investigación es la construcción y evaluación psicométrica de siete categorías de tareas de recuerdo y reconocimiento para la medición de la memoria teatral de jóvenes espectadores, basadas en los respetivos códigos teatrales de una representación específica para audiencias infantiles. El propósito de estas tareas es la evaluación de los recuerdos mnemónicos de los jóvenes espectadores recordando el nivel de a) las representaciones de los personajes en el escenario (actuación), b) el marco visual de la representación, c) el código auditivo, d) las luces, e) el texto dramático, f) la trama/acción, y g) la técnica del teatro de sombras.

El recuerdo y reconocimiento de tareas se construyeron de acuerdo al Classical Test Theoriy of Question Analysis en una muestra de alumnado de 5o grado de Educación Primaria, quien vio esta representación específica dirigida a un público infantil, y fue evaluada con el método de Análisis Factorial. Para la evaluación de la calidad de las preguntas, consideramos el coeficiente de dificultad de cada pregunta, el coeficiente discriminador y la evaluación del nivel de correlación por jueces expertos. Para el control psicométrico de los test examinamos la validez de sus construcciones conceptuales a través del análisis factorial y el coeficiente de validez interna.

El resultado de las tareas expuestas fue la creación de siete herramientas de medida fiables y válidas, en las cuales no se infirieron efectos en la variable de género.

Palabras clave: Classical Test Theory of Question Analysis, memoria teatral, jóvenes espectadores, tareas de recuerdo, tareas de reconocimiento, evaluación psicométrica.

\section{Resum}

L'objectiu d'aquesta recerca és la construcció i avaluació psicomètrica de set categories de tasques de record i reconeixement per a la mesura de la memòria teatral de joves espectadors, basades en els respectius codis teatrals d'una representació específica per a audiències infantiles. El propòsit d'aquestes tasques és l'avaluació dels records mnemònics dels joves espectadors tot recordant en un nivell de a) les representacions dels personatges a l'escenari (actuació), b) el marc visual de la representació, c) el codi auditiu, d) la llum, e) el text dramàtic, f) la trama/acció, i g) la tècnica del teatre d'ombres.

El record i reconeixement de tasques es van construir d'acord amb el Classical Test Theoriy of Question Analysis en una mostra d'alumnat de 5é grau d'Educació Primària, el qual ha vist aquesta representació específica adreçada a un públic infantil, i va ser avaluat amb el mètode d'Anàlisi Factorial. Per a l'avaluació de la qualitat de les preguntes, consideràrem el coeficient de dificultat de cada pregunta, el coeficient discriminador i l'avaluació del nivell de correlació per jutges experts. Per al control psicomètric dels tests vam examinar la validesa de les seues construccions conceptuals a través de l'anàlisi factorial i el coeficient de validesa interna.

El resultat de les tasques exposades va ser la creació de set eines de mesura fiables i vàlides, en les quals no s'hi van inferir efectes en la variable gènere.

Paraules clau: Classical Test Theory of Question Analysis, memòria teatral, joves espectadors, tasques de record, tasques de reconeixement, avaluació psicomètrica. 


\section{Introduction}

The notion and function of the young spectator's theatrical memory has concerned Theatre Studies research because of the interest concerning the reception and perception/acceptance of a theatre performance by the spectators' conscience. Memory as a function of the preservation of information of the past, refers to a sum of physical functions, with which humans may activate impressions, images and situations that even if they took place in the Past, they may be recollected as if they were present (Schacter, 2001). This activation and re-creation of the Past into the Present, is accordingly adapted to the individual or collective needs and expectations of the Present.

(Radstone \& Schwarz, 2010). The multi-dimensional notion

The establishment of information in the Longterm Memory and its successful retrieval, depends on the successful encoding (process, organization, relevant encoding and retrieval frame) and storage in the equivalent brain regions. The loss of information is usually ascribed to its depreciation or to the intervention of other information. of memory, together with its respective content is depicted in its various representations, i.e. individual recollection, collective memory and tradition. In the same way, the angle and its approach differs at times, as it emphasizes on its intent or random, on its private or public, on its conscious or subconscious character. (Olick, 2007: 111-112, Casey, 2000).

Memory demands all the information that comes from the exterior surrounding world and is sensorially recorded, first to be encoded, then stored and finally retrieved. In the first stage of sensory recording, the information is not accurately identified; only some of its characteristics (size, color, position etc.) are identified. The sensory recordings are analyzed into optical, tangible, audio ones and so on. They have a very short retention span. A very small part of it passes to the Short-term Memory (Working Memory), which has very small capacity and retains the encoded informative elements in order to perform certain processes essential for the survival and transmission to the Long-term Memory (Multi-store Memory) (Bablekou, 2003). If the information is retained there for more than a few seconds, it is then transmitted to the Long-term Memory, where it may remain infinitely. According to Roussos (2011), what is stored to Long-term Memory is defined by the type of process (encoding, revision, attention) that takes place in the Short-term Memory. Long-term Memory has unlimited capacity of quantitative and time information retention and may be divided into fact, episodic, semantic and procedural memory. The establishment of information in the Long-term Memory and its successful retrieval, depends on the successful encoding (process, organization, relevant encoding and retrieval frame) and storage in the equivalent brain regions. The loss of information is usually ascribed to its depreciation or to the intervention of other information.

\section{Theatre codes and the young spectator's memory}

A plethora of semiotic systems is involved in the field of Theatre Studies. These represent a wide range of functionality and mobility of the individual elements, with an equivalent wealth of decoding abilities and possibilities that are easily adjusted to the various subjective and objective, 
measurable and non-measurable factors that affect the spectator's reception (Elam, 2002). The spectator's view on theatre (for a specific performance or in general) is probably a result of all the incongruous and the relevant elements that directly or indirectly derive from the notion of memory (Grammatas, 2017). However, how does memory -especially the young spectators' memoryfunction? Which is the relation between memory and the event itself (Schacter, 2001)? How does the subject proceed to categorizations, with which criteria and for what reasons? Especially for the juvenile audience, what is it that remains in the memory after a performance? Of course, there is no question that the performance on stage as a vehicle of intense emotions, reinforces mnemonic recordings and activates memories. Excitation increases the possibility of memory consolidation during the encoding phase and the storing of information phase (Bablekou, 2011). Theatrical memories derive from the spectator's constant intervention on the elements of the spectacle that s/he chooses, constructs, interprets, connects and reconstructs.

According to Balme (2008), the plethora of the cognitive and emotional reactions, along with the mental actions and interpretative interventions that appear when someone sees a performance, are affected by a number of differentiating factors that define the way spectators receive a performance. Some of those are the age, the educational level, the span of attention, the collective experiences, the gender, the nationality, or even the venue that action takes place. Thus, apart from the objective reception conditions, the subjective ones (expectations, interests, attitudes, experiences, pre-existing knowledge and so on) affect the function of the young spectator's memory. The spectator's emotional identification with the character/hero or the experiential methexis, his/her kinesthetic involvement with the action on stage, the adaptation of the imaginary scenic world to his/her own illusory condition, are also elements that lead to the activation and development of mnemonic mechanisms. At this particular phase of the development of his/her personality and because of the peculiarity of the shaping of his/her psychic mechanism and social conscience, the young spectator focuses on those elements of the performance that attract his/her interest and are closer to his/her mentality. These specific elements reinforce the interactive communication that functions during the performance between the audience and the stage, challenge the attention and excitement and eventually manage to activate mnemonic recording. The actors' speech, the phrases and notions with their content of values, activate the audience's conscience and in combination with the auditory and visual stimuli challenged by secondary theatre codes (such as scenography, décor, costumes), are the elements that may activate function, which leads to the creation and storage of memory, on a micro and a macro-level (Grammatas, 2011).

Theatre codes act drastically on the spectator's memory and intensify or weaken the oblivion caused by time distance of the acting persons' dramatic and scenic space and time on the one side and the objective space and time on the other

Theatre codes act drastically on the spectator's memory and intensify or weaken the oblivion caused by time distance of the acting persons' dramatic and scenic space and time on the one side and the objective space and time on the other [...]. Apart from that, the dramatic elements of the play also affect mnemonic recording 
(Grammatas, 2011). Apart from that, the dramatic elements of the play also affect mnemonic recording. The topics of the play (folk tradition, modern thematic area, ancient Greek literature, children's literature and so on), the kind/type (dramatic play, devised theatre, intertextual assemblage, adaptation and so on), the language, the style of writing, the ideological/value system of the play, the reference to the Present, the structure of the plot, the element of "adventure", also activate the mnemonic mechanism. It is unquestionable that the actor's presence as the living power of the performance and crucial point of the spectacle on stage, is strongly depicted on the young spectator's memory. Acting is a highly complex method that consists of a variety of individual elements. Those elements are certain to affect the creation of memories, depending on the way and the dynamics with which they are involved in the scenic venture. Thus, kinesiology, voice quality, mimicry, the use of paralinguistic features etch their traces on the young spectator's memory, by underlying and promoting the heroes' characteristics and creating intense emotions, with a predisposition to empathize and participate in what is happening on stage (Papakosta, 2010). Other basic acting elements such as artful innocence, expressiveness, authenticity, resourcefulness, extroversion, immediacy, and eagerness for communication, play a very important role in theatrical communication and subsequently in mnemonic recording. The spectator's emotional identification with the hero (-with the actor being a mediator-), challenges the experiential methexis of what is happening on stage to a high degree and functions as the driving force for the creation and development of memory. Some other mnemonic traces may be etched by the actors' appearance and concern the costumes, the make-up, the hairstyling, the masks and so on), the speech on stage (direct, simple-not simplistic, experiential, vivid and so on).

Moreover, some characteristics on stage direction, such as the use of theatre techniques (alienation effect, corporality, new technologies, participation, dramatic narrative, Shadow Theatre figures, which are very popular in Greece and so on), the aesthetic line (view) , the "mise-en-scène", (i.e. the arrangement of the scenery props on the stage of a theatrical performance-the setting) and other elements of children's play (familiar to young spectators) such as animation, the "unforeseen", contradiction/contrast, repetition, imagination and surprise, may contribute to the creation of memories. Also, the element of the "unforeseen", the unexpected, the "different", stirs the child's imagination, stimulates his/her interest and activates mnemonic recorder.

The quality of the visual arts frame (costumes, stage design, stage objects and mechanisms etc.), and the way all these are realized on stage, (resourcefulness, imagination, innovation, flexibility, ability to change, non-mimic aesthetics, unpredictable combinations and unusual materials, loans from children's play and so on), is also another factor of successful mnemonic recording. The adaptation of the artistic frame according to textual, kinesiological, spatial, aesthetic, pedagogical and psychological needs, the modulation with the aesthetic identity of the performance, also affects the creation of memories. We take for granted that "the distance between the stage object and what this represents, its ability to challenge different situations, is a factor that contributes to the establishment of memory" (Deldime, 1996: 102-103). Unconventional costumes, innovative and resourceful solutions concerning the development, transformation and creation of intertextual 
assemblages may cause surprise, curiosity, excitement, stir the young spectators' imagination and activate their mnemonic recording.

The way secondary theatre codes such as lights and music are exploited, which may easily be transformed into primary codes and become the foremost exponents of stage direction, is possible to create strong memories. In this particular type of theatre, music and lights may create a unique atmosphere, emotionally charge or defuse action, comment on persons and circumstances, fascinate and thrill with their intense emotional power, challenge concentration, interest, curiosity and surprise. They may activate and reinforce the mnemonic recorder when they act corroboratively, explanatorily, additionally and emphatically on the stage action, thus causing emotional and physical reactions. Moreover, lights and music in combination with the actor's kinesiological and mimic code, may create indelible mnemonic traces.

When the use of new technologies is orientated and functionally aligned towards the director's basic target, then it may arouse the young spectator's interest and via familiar codes manage to etch its elements on memory. The projections in particular, may modify the scenic image, denote emotions or the heroes' deeper thoughts, make time/spatial transitions in the play much easier for the young spectators to perceive, undermine, reinforce or even reverse the scenic action, thus developing and reinforcing mnemonic recording.

Shadow Theatre is a technique that may contribute to the activation and creation of memories by participating in the director's attempt in an auxiliary or primary way: the Shadow Theatre figures may be projected on a panel at the background of the stage and create a scene that explains or adds extra information to what is already happening in the foreground, thus creating a unique atmosphere. With its strong semiotic function, it supports the direct access to the young spectator's world of senses and emotions, thus creating a fertile land for mnemonic traces. It activates the young spectator's imagination and interest, challenge him/her kinesthetically, while it simultaneously broadens the acting abilities and emphasizes on theatricality. It may substitute or modify the scenic image, intervene on the time/spatial flow and the sound environment of the performance, replace, complete or continue the action. More than that, it may reinforce participation or alienation according to the director's view.

\section{Method}

\subsection{The aim of the research}

The present study aims at the construction and psychometric evaluation of seven recall and recognition tasks for the measurement of the spectator's theatrical memory, based on the respective theatre codes of a specific performance for young spectators. Particularly, the study aims at the evaluation and selection of the items that will constitute each test, according to the Classical Test Theory (Alexopoulos, 1998). The aim of CTT is (generally speaking) to understand and improve the reliability of psychological tests and was 
codified as we know it today by Novick (1966) and described in classical texts such as Lord \& Novick (1968) and Allen \&Yen (2002). Based therefore on this theory, we are going to evaluate the items' difficulty and differentiation index, along with the degree of accordance of expert judges for every task of the test. Also, we are going to examine the Factorial validity of the tasks that will emerge, and the reliability of their internal consistency.

The ultimate purpose of those tasks is valid and reliable quantitative evaluation of the mnemonic recording on a level of a) the (actors') acting, b) the visual frame of the performance, c) the audio code, d) the lights, e) the dramatic text, f) the plot/action and g) the Shadow Theatre technique.

\subsection{Participants}

The selection of the participants for the construction of the recall and recognition tasks for the measurement of the spectator's theatrical memory took place in the School Year 20182019 on $5^{\text {th }}$ Grade Primary School pupils (i.e. 10 year old pupils) that attended the performance "Boy with a suitcase" (by British playwright Mike Kenny, "Boy with a suitcase", Plays for young audiences, 2008, 120 pages), translated and adapted in Greek by Xenia Kalogeropoulou (actress and pioneer in Children's Theatre in Greece for years on) and directed by Elias Karellas in Kappa Theatre (Athens, Greece), within the frame of their cultural visits program. With this play, the playwright is aspiring to raise the awareness of the major refugee problem and the issue of forced and violent migration. It is the story of a 12-year-old boy, Naz, who undertakes a long and dangerous journey abroad, because his homeland is destroyed by war, to make way to his elder brother's home. He carries a small suitcase and a treasure of stories from his childhood and fancies himself like Sinbad-a man of many voyages and endless stories. Despite the fact that his life is not "heaven on earth" after all, Naz realizes that happiness will always exist as long as he keeps his stories alive. The specific performance was selected with clear pedagogical and artful criteria, for its aesthetic line and the director's view, the use of certain techniques, and the wealth of systems and communication channels. Another criterion that counted, was that it balanced harmoniously between artistic awareness and pedagogical aim.

In this research 58 Primary School pupils in Athens participated. 27 of them (46.6\%) were boys and 31 (53.4\%) were girls. Pupils with severe developmental problems or sensory/mental disorders were excluded. Their participation came after their teachers' desire to contribute to the realization of this research, with the pupils' involvement in it and their parents' written informed consent. The selection of the specific age group was not random. We chose pupils that had entered preadolescence, partly because it is an important, sensitive period and a stage of human development 
following early childhood and preceding adolescence: therefore, at that particular age pupils may well view human relationships differently, notice the flawed human side and begin to develop a sense of identity. The most important reason, however, is that at that particular stage there are fewer time influences concerning the quality of the stored information (Siegler, 2013). $5^{\text {th }}$ Grade pupils have broader mnemonic capacity in comparison with younger pupils and exploit more satisfactorily higher and basic mnemonic recording processes. Also, they exploit mnemonic strategies in a more flexible way and have a greater cultural awareness concerning the handling of memory (Siegler, 2013).

Also, members of the Academic staff of the National and Kapodistrian University of Athens with relevant experience took part in this research as expert judges for the conceptional validity of the structural elements of recall and recognition tasks. Those too, had also seen the performance mentioned above.

\subsection{Instrument}

In order to construct the recall and recognittion tasks, we initially formed a sum of 62 items based on the dramatic text and the theatre codes of the performance "Boy with a suitcase". Every item was accompanied by three alternative answers, of which only one was correct and referred to a) the (actors') acting, b) the visual frame of the performance, c) the audio frame of the performance, d) the lights, e) the dramatic text, f) the plot/action and g) the Shadow Theatre technique. Initially, on a pilot phase, the items were handed out to ten $5^{\text {th }}$ Grade pupils in order to check the content from a linguistic point of view and then to the participants of the study in the form of a questionnaire. Every correct answer of the participants was marked with one (1) point, whereas every wrong one with zero (0) points. The final version of the tasks, based on the results of statistic and factor analysis that followed, included 32 elements structured on seven thematic factors. Indicative items for each thematic factor are included in the Appendix of the study.

\subsection{Process}

The total of the initial items that included the recall and recognition tasks was handed out to the participants of the study the day after the performance, by the teacher of the class together with the researchers. Before completing, the pupils were encouraged to read them carefully and choose the ones that they considered correct, based on what they remembered from the performance. The average time needed for the completion of the questionnaire was 45 minutes. After the completion, the questionnaires were gathered, listed, graded by the research team and analyzed quantitively with SPSS 21 (Field, 2013).

Simultaneously to the above process, three freelance experts were called to evaluate the questions one to one and classify them according to their content to a priori defined thematic factors/theatre codes.

\subsection{Analysis}


The construction of the seven recall and recognition tasks was formed according to the Classical Test Theory of Question Analysis and the Factor Analysis method (Kline, 1999). As a process, it included the evaluation per each code for a) the difficulty index, b) the differentiation of each initial question index, c) the evaluation of the freelance experts' degree of agreement for each question, d) the examination of the validity of each task and finally e) its reliability (Hinkin, Tray\& Enz, 1997).

More specifically, there was a check conducted for the degree of difficulty (DIF) of each question in order to evaluate how each one responded to the level of the persons examined. This was calculated per question by the quotient of the correct answers to the number of the examined that answered that particular question, with ideal value for triple choice answers, from .46 up to .86 (Aiken, 1994, Alexopoulos 1998, Gregory, 1992).

Consequently, we calculated the differentiation index (DEF) of each question via the quotient between the number of those with high and low total score on the test and have answered the question correctly to the number of the persons asked. Thus, we evaluated the contribution of each question to the differentiation of the measurement of the theatrical memory of the participants with values higher than .20 to be considered acceptable (Alexopoulos, 1998).

As for the evaluation of the freelance experts' degree of agreement concerning the categorization of each question according to its thematic content to the thematic axes/theatre codes of a) acting, b) visual frame, c) audio frame, d) lights, e) dramatic text, f) plot/action and g) Shadow Theatre technique, the Fleiss' kappa index (Fk) of agreement was exploited. Values close to 1 denote total agreement between the experts, whereas values close to 0, total disagreement (Falotico \& Quatto, 2015).

Within a range of explanatory factor analysis (EFA), we attempted to evaluate the Factorial validity of the recall and recognition tasks per theatre code (Clark \& Watson, 1995; De Vellis, 2003; Nunnally \& Bernstein, 1994). During the EFAs in order to define the number of factors, we used the Kaiser-Meyer-Olkin criterion, based on which factors with eigenvalue lower than 1, are not considered statistically important and questions with loading $\geq .5$ were considered important variables for the formation of the factor (Biassuti \& Frate, 2017).

Finally, we used the Cronbach's Alpha $(\alpha)$ coefficient in order to check the reliability of the tests (Cortina, 1999). Also, we evaluated the existence of gender differences on the tests with the MannWhitney criterion on a $1 \%$ level of statistical significance $(p<.001)$

\section{Results}

\subsection{Component matrix for the (actors') acting elements}

The data analysis of the five items concerning the (actors') acting code resulted in a difficulty index between .22-.91 and a differentiation index between .16-.57. It was thus decided to remove the tenth item because the values in the difficulty and differentiation index and the Fleiss' kappa 
$(\mathrm{Fk}=.33)$ were not satisfactory. Also, with the removal of this item the Cronbach $\alpha$ index would be considerably improved (see: Table 1).

\begin{tabular}{|c|c|c|c|c|}
\hline Item & DIF & DEF & Fk & $\begin{array}{c}\alpha \text { if } \\
\text { item deleted }\end{array}$ \\
\hline 10 & 0.22 & 0.16 & 0.33 & 0.81 \\
\hline 14 & 0.91 & 0.50 & 1.00 & 0.56 \\
\hline 17 & 0.89 & 0.43 & 1.00 & 0.62 \\
\hline 58 & 0.76 & 0.57 & 1.00 & 0.60 \\
\hline
\end{tabular}

Table 1. Item analysis for the (actors') acting code

By removing item 10, the corrected item-total correlation fluctuated from .59 to .73, the squared multiple correlation between $37 \%$ and $63 \%$ and the Cronbach $\alpha$ index was found equal to .81. The above index values are considered satisfactory.

\begin{tabular}{|c|c|c|c|c|}
\hline Item & Loadings & $\mathbf{M}$ & $\mathbf{S d}$ & $\mathbf{h}^{2}$ \\
\hline 14 & 0.88 & 0.84 & 0.37 & 0.78 \\
\hline 50 & 0.81 & 0.79 & 0.41 & 0.66 \\
\hline 17 & 0.79 & 0.91 & 0.28 & 0.63 \\
\hline 38 & 0.75 & 0.74 & 0.44 & 0.56 \\
\hline
\end{tabular}

Table 2. Component matrix for the (actors') acting factor template

Bartlett's sphericity test was statistically important $\left(\chi^{2}(6)=89.79, \mathrm{p}<.001\right.$ and the Kaiser-MeyerOlkin Measure $(\mathrm{KMO})=.73$, a satisfactory value according to analysis patterns (Worthington \& Whittaker, 2006). One factor that explicates the $65.50 \%$ of Total Variance explained of the variables under analysis was selected by taking into consideration the Kaiser criterion. The communality $\mathrm{h}^{2}$ values of the elements of the univariate model fluctuated from .56 to .78 with an average value of .66 points, an eigenvalue of 2.62 and loadings fluctuating from .75 to .88 (see: Table 2 ).

\subsection{Component matrix for the visual frame of the performance}

From the data analysis of the 16 items concerning the visual frame theatre code, it came out that the difficulty index of the items fluctuated from .59 to 1.00 and the differentiation index from .40 to .60. It was decided to remove items 4, 6, 16, 28, 40, 52 and 56 because of the low value in the Fleiss' kappa index. Items 9, 20, 28, 31 and 52 were also removed because they presented a high value in the difficulty index. Finally, item 57 was removed too because it presented a low differentiation index (see: Table 3).

\begin{tabular}{|c|c|c|c|c|}
\hline Item & DIF & DEF & Fk & $\begin{array}{c}\alpha \text { if } \\
\text { item deleted }\end{array}$ \\
\hline 2 & 0.69 & 0.60 & 1.00 & 0.64 \\
\hline 4 & 0.71 & 0.40 & 0.00 & 0.71 \\
\hline 6 & 0.98 & 0.53 & 0.33 & 0.65 \\
\hline 9 & 0.98 & 0.50 & 1.00 & 0.68 \\
\hline 20 & 0.94 & 0.50 & 0.33 & 0.69 \\
\hline 21 & 1.00 & 0.52 & 1.00 & 0.68 \\
\hline 28 & 0.97 & 0.59 & 1.00 & 0.64 \\
\hline 31 & 0.98 & 0.53 & 0.33 & 0.65 \\
\hline
\end{tabular}




\begin{tabular}{|c|c|c|c|c|}
\hline 32 & 0.91 & 0.59 & 1.00 & 0.64 \\
\hline 40 & 0.65 & 0.45 & 0.33 & 0.69 \\
\hline 41 & 0.76 & 0.60 & 1.00 & 0.63 \\
\hline 52 & 0.78 & 0.60 & 1.00 & 0.63 \\
\hline 56 & 0.93 & 0.55 & 0.33 & 0.66 \\
\hline 57 & 0.59 & 0.45 & 0.33 & 0.68 \\
\hline
\end{tabular}

Table 3. Item analysis for the visual frame of the performance code

After the removal of the above items, the corrected item-total correlation fluctuated from .48 to .72. Also, the squared multiple correlation was calculated between $29 \%$ and $60 \%$ and the Cronbach's $\alpha$ index was found equal to .82. The above index values are considered satisfactory according to analysis patterns.

\begin{tabular}{|c|c|c|c|c|}
\hline Item & Loadings & M & Sd & $\mathbf{h}^{2}$ \\
\hline 2 & 0.71 & 0.81 & 0.40 & 0.49 \\
\hline 21 & 0.64 & 0.93 & 0.26 & 0.41 \\
\hline 32 & 0.82 & 0.90 & 0.32 & 0.68 \\
\hline 41 & 0.84 & 0.74 & 0.44 & 0.71 \\
\hline 45 & 0.82 & 0.78 & 0.42 & 0.67 \\
\hline
\end{tabular}

Table 4. Component matrix for the visual frame factor template

Bartlett's sphericity test was statistically important $\left(\chi^{2}(10)=118.41, \mathrm{p}<.001\right)$ and the KaiserMeyer-Olkin Measure (KMO)=.75, a satisfactory value according to analysis patterns (KMO>.6). One factor that explicates the $59.12 \%$ of Total Variance explained of the variables under analysis was selected by taking into consideration the Kaiser criterion. The fluctuation of the elements of the univariate model that emerged, fluctuated from .41 to .71 with an average value of .59 points, an eigenvalue of 2.96 and loadings fluctuating from .64 to .84 (see: Table 4).

\subsection{Component matrix for the audio code of the performance}

The results of data analysis for the five items concerning the audio code of the performance, showed that the difficulty index of the items fluctuated from .59 to .86 and the differentiation index from .24 to .55 . Item 11 was decided to be removed for the considerable improvement of the Cronbach $\alpha$ index (see: Table 5).

\begin{tabular}{|c|c|c|c|c|}
\hline Item & DIF & DEF & Fk & $\begin{array}{c}\alpha \text { if } \\
\text { item deleted }\end{array}$ \\
\hline 11 & 0.62 & 0.24 & 1.00 & 0.77 \\
\hline 24 & 0.59 & 0.55 & 1.00 & 0.49 \\
\hline 25 & 0.76 & 0.45 & 1.00 & 0.51 \\
\hline 37 & 0.74 & 0.45 & 1.00 & 0.53 \\
\hline
\end{tabular}

Table 5. The audio code of the performance item analysis

After the removal of item 11, the corrected item-total correlation fluctuated from .39 to .69. Also, the squared multiple correlation was calculated between $18 \%$ and $50 \%$ and the Cronbach's $\alpha$ was found equal to .77. The above index values are considered satisfactory according to analysis patterns. 


\begin{tabular}{|c|c|c|c|c|}
\hline Item & Loadings & $\mathbf{M}$ & $\mathbf{S d}$ & $\mathbf{h}^{2}$ \\
\hline 24 & 0.86 & 0.66 & 0.48 & 0.73 \\
\hline 25 & 0.84 & 0.79 & 0.41 & 0.70 \\
\hline 26 & 0.78 & 0.76 & 0.43 & 0.61 \\
\hline 37 & 0.59 & 0.86 & 0.35 & 0.35 \\
\hline
\end{tabular}

Table 6. Component matrix for the audio code factor template

Bartlett's sphericity test was statistically important $\left(\chi^{2}(6)=64.95, \mathrm{p}<.001\right)$ and the Kaiser-MeyerOlkin Measure $(\mathrm{KMO})=.74$, a satisfactory value according to analysis patterns (Worthington \& Whittaker, 2006). One factor that explicates the $59.83 \%$ of Total Variance explained of the variables under analysis was selected by taking into consideration the Kaiser criterion. The fluctuation of the elements of the univariate model that emerged, fluctuated from .59 to .86 with an average value of .77 points, an eigenvalue of 2.39 and loadings fluctuating from .59 to .86 (see: Table 6 ).

\subsection{Component matrix for the lights of the performance}

The results of data analysis for the five items concerning the lights of the performance, showed that the difficulty index of the items fluctuated from .13 to .62 and the differentiation index from .16 to .38. It was decided to remove item 47 for the considerable improvement of the Cronbach $\alpha$ index and because of the fact that it presented a low differentiation index (see: Table 7).

\begin{tabular}{|c|c|c|c|c|}
\hline Item & DIF & DEF & Fk & $\begin{array}{c}\boldsymbol{\alpha} \text { if } \\
\text { item deleted }\end{array}$ \\
\hline 7 & 0.62 & 0.38 & 1.00 & 0.46 \\
\hline 12 & 0.29 & 0.26 & 1.00 & 0.45 \\
\hline 47 & 0.64 & 0.16 & 0.33 & 0.73 \\
\hline 5 & 0.13 & 0.29 & 1.00 & 0.35 \\
\hline
\end{tabular}

Table 7. Item analysis for the lights of the performance

After the removal of item 47, the corrected item-total correlation fluctuated from .46 to .64. Also, the squared multiple correlation was calculated between $23 \%$ and $43 \%$ and the Cronbach's $\alpha$ was found equal to .73. The above index values are considered satisfactory according to analysis patterns.

\begin{tabular}{|c|c|c|c|c|}
\hline Item & Loadings & $\mathbf{M}$ & $\mathbf{S d}$ & $\mathbf{h}^{2}$ \\
\hline 7 & 0.73 & 0.59 & 0.50 & 0.53 \\
\hline 12 & 0.82 & 0.33 & 0.47 & 0.67 \\
\hline 55 & 0.87 & 0.29 & 0.46 & 0.75 \\
\hline
\end{tabular}

Table 8. Component matrix for the lights factor template

Bartlett's sphericity test was statistically important $\left(\chi^{2}(3)=38, p<.001\right)$ and the Kaiser-MeyerOlkin Measure $(\mathrm{KMO})=.64$, a satisfactory value according to analysis patterns (Worthington \& Whittaker, 2006). One factor that explicates the $65.26 \%$ of Total Variance explained of the variables under analysis was selected by taking into consideration the Kaiser criterion. The fluctuation of the 
elements of the univariate model that emerged, fluctuated from .53 to .75 with an average value of .65 points, an eigenvalue of 1.96 and loadings fluctuating from .73 to .87 (see: Table 8).

\subsection{Component matrix for the dramatic text}

The results of data analysis for the eleven items concerning the content of the performance, showed that the difficulty index of the items fluctuated from .71 to .98 and the differentiation index from .57 to .76 .

\begin{tabular}{|c|c|c|c|c|}
\hline Item & DIF & DEF & Fk & $\begin{array}{c}\alpha \text { if } \\
\text { item deleted }\end{array}$ \\
\hline 1 & 0.98 & 0.67 & 1.00 & 0.64 \\
\hline 5 & 0.94 & 0.67 & 1.00 & 0.60 \\
\hline 8 & 0.89 & 0.76 & 1.00 & 0.53 \\
\hline 15 & 0.95 & 0.74 & 1.00 & 0.56 \\
\hline 23 & 0.96 & 0.72 & 1.00 & 0.57 \\
\hline 46 & 0.95 & 0.71 & 1.00 & 0.54 \\
\hline 49 & 0.86 & 0.72 & 1.00 & 0.58 \\
\hline 53 & 0.95 & 0.67 & 1.00 & 0.60 \\
\hline & 0.71 & 0.57 & 0.00 & 0.66 \\
\hline
\end{tabular}

Table 9. Item analysis on the scenario of the performance

It was decided to remove items 1, 48, 49 and 53 for the considerable improvement of the Cronbach $\alpha$ index. Especially for items 49 and 53 the expert judges' low agreement index (Fk), and the high difficulty index for item 1 (see: Table 9). After the removal of the above items, the corrected itemtotal correlation fluctuated from .37 to .60. Also, the squared multiple correlation was calculated between $21 \%$ and $44 \%$ and the Cronbach's a was found equal to .73 . The above index values are considered satisfactory according to analysis patterns.

Bartlett's sphericity test was statistically important $\left(\chi^{2}(21)=82.50, p<.001\right)$ and the Kaiser-MeyerOlkin Measure (KMO)=.73, a satisfactory value according to analysis patterns (KMO>.6). One factor that explicates the $40.60 \%$ of Total Variance explained of the variables under analysis was selected by taking into consideration the Kaiser criterion. The fluctuation of the elements of the univariate model that emerged, fluctuated from .32 to .49 with an average value of 0.41 points, an eigenvalue of 2.84 and loadings fluctuating from .57 to .75 (see: Table 10 ).

\begin{tabular}{|c|c|c|c|c|}
\hline Item & Loadings & $\mathbf{M}$ & $\mathbf{S d}$ & $\mathbf{h}^{2}$ \\
\hline 5 & 0.57 & 0.95 & 0.22 & 0.32 \\
\hline 8 & 0.64 & 0.90 & 0.31 & 0.40 \\
\hline 15 & 0.64 & 0.95 & 0.22 & 0.41 \\
\hline 18 & 0.75 & 0.97 & 0.18 & 0.56 \\
\hline 39 & 0.70 & 0.95 & 0.22 & 0.49 \\
\hline 46 & 0.58 & 0.86 & 0.35 & 0.34 \\
\hline
\end{tabular}

Table 10. Component matrix for the scenario factor template

\subsection{Component matrix for the plot and action elements}


The data analysis for the eleven items concerning the elements of the plot and the action of the performance, showed that the difficulty index of the items fluctuated from .66 to .95 and the differentiation index from .16 to .36 .

\begin{tabular}{|c|c|c|c|c|}
\hline Item & DIF & DEF & Fk & $\begin{array}{c}\alpha \text { if } \\
\text { item deleted }\end{array}$ \\
\hline 19 & 0.66 & 0.28 & 1.00 & 0.72 \\
\hline 29 & 0.83 & 0.28 & 1.00 & 0.64 \\
\hline 30 & 0.95 & 0.16 & 1.00 & 0.68 \\
\hline 33 & 0.83 & 0.28 & 1.00 & 0.65 \\
\hline 45 & 0.95 & 0.19 & 1.00 & 0.70 \\
\hline 51 & 0.83 & 0.24 & 1.00 & 0.71 \\
\hline 58 & 0.91 & 0.22 & 1.00 & 0.66 \\
\hline 59 & 0.93 & 0.21 & 0.33 & 0.66 \\
\hline 60 & 0.81 & 0.33 & 1.00 & 0.63 \\
\hline
\end{tabular}

Table 11. Item analysis on the plot and the elements of action of the performance

It was decided to remove item 52 because of the low expert judges' agreement and items 30 and 35 because of the low differentiation grade they presented (<.2). Also, for the considerable improvement of the Cronbach $\alpha$ index (see: Table 11), items 19 and 42 were removed. After the removal of the above items, the corrected item-total correlation fluctuated from .36 to .62. Also, the squared multiple correlation was calculated between $24 \%$ and $52 \%$ and the Cronbach's $\alpha$ was found equal to .78. The above index values are considered satisfactory according to analysis patterns.

\begin{tabular}{|c|c|c|c|c|}
\hline Item & Loadings & $\mathbf{M}$ & $\mathbf{S d}$ & $\mathbf{h}^{2}$ \\
\hline 29 & 0.74 & 0.83 & 0.38 & 0.55 \\
\hline 33 & 0.77 & 0.83 & 0.38 & 0.60 \\
\hline 51 & 0.51 & 0.91 & 0.28 & 0.26 \\
\hline 58 & 0.70 & 0.81 & 0.40 & 0.48 \\
\hline 59 & 0.60 & 0.84 & 0.37 & 0.35 \\
\hline 60 & 0.77 & 0.74 & 0.44 & 0.60 \\
\hline
\end{tabular}

Table 12. Component matrix for the plot and action factor template

Bartlett's sphericity test was statistically important $\left(\chi^{2}(15)=97.33, \mathrm{p}<.001\right)$ and the Kaiser-MeyerOlkin Measure $(\mathrm{KMO})=.65$, a satisfactory value according to analysis patterns (Worthington \& Whittaker, 2006). One factor that explicates the $47.35 \%$ of Total Variance explained of the variables under analysis was selected by taking into consideration the Kaiser criterion. The fluctuation of the elements of the univariate model that emerged, fluctuated from 0.26 to 0.60 with an average value of .47 points, an eigenvalue of 2.84 and loadings fluctuating from .51 to .77 (see: Table 12 ).

\subsection{Component matrix for Shadow Theatre technique}

The data analysis for the eleven items concerning Shadow Theatre, a part of the visual spectacle of the performance, showed that the difficulty index of the items fluctuated from .49 to .96 and the differentiation index from .16 to .38 . 


\begin{tabular}{|c|c|c|c|c|}
\hline Item & DIF & DEF & Fk & $\begin{array}{c}\alpha \text { if } \\
\text { item deleted }\end{array}$ \\
\hline 3 & 0.47 & 0.36 & 0.33 & 0.52 \\
\hline 13 & 0.95 & 0.33 & 1.00 & 0.45 \\
\hline 22 & 0.84 & 0.33 & 0.00 & 0.49 \\
\hline 27 & 0.66 & 0.38 & 0.00 & 0.48 \\
\hline 34 & 0.84 & 0.36 & 0.33 & 0.52 \\
\hline 43 & 0.50 & 0.26 & 1.00 & 0.60 \\
\hline 44 & 0.96 & 0.31 & 1.00 & 0.49 \\
\hline 61 & 0.96 & 0.31 & 1.00 & 0.49 \\
\hline 62 & 0.67 & 0.33 & 0.33 & 0.52 \\
\hline
\end{tabular}

Table 13. Item analysis on Shadow Theatre elements

It was decided to remove items $3,22,27,34,54$ and 61 because of the low expert judges' agreement, item 36 for the considerable improvement of the Cronbach $\alpha$ index, together with element 62 because of the low differentiation grade they presented (<.2), (see: Table 13). After the removal of the above items, the corrected item-total correlation fluctuated from .38 to .79 . Also, the squared multiple correlation was calculated between $22 \%$ and $42 \%$ and the Cronbach's $\alpha$ was found equal to .79. The above index values are considered satisfactory according to analysis patterns.

\begin{tabular}{|c|c|c|c|c|}
\hline Item & Loadings & $\mathbf{M}$ & $\mathbf{S d}$ & $\mathbf{h}^{2}$ \\
\hline 13 & 0.60 & 0.95 & 0.22 & 0.36 \\
\hline 43 & 0.96 & 0.96 & 0.19 & 0.93 \\
\hline 44 & 0.97 & 0.97 & 0.18 & 0.94 \\
\hline
\end{tabular}

Table 14. Shadow Theatre elements factor template

Bartlett's sphericity test was statistically important $\left(\chi^{2}(3)=39.52, p<.001\right)$ and the Kaiser-MeyerOlkin Measure (KMO)=.61, a satisfactory value according to analysis patterns (Worthington \& Whittaker, 2006). One factor that explicates the $55.26 \%$ of Total Variance explained of the variables under analysis was selected by taking into consideration the Kaiser criterion. The fluctuation of the elements of the univariate model that emerged, fluctuated from .36 to .94 , with an average value of .75 points, an eigenvalue of 2.24 and loadings fluctuating from .60 to .97 (see: Table 14).

\subsection{Gender influence and additional analyses evaluation}

Based on the exploitation of the Mann-Whitney criterion of individual samples for the examination of possible gender differences on the values of individual recall and recognition tasks, no statistically considerable difference was noticed, concerning gender in relation with the (actors') acting code ( $\mathrm{z}=-.61, p=.54)$, the visual code $(\mathrm{z}=-1.05, p=.30)$, the lights $(\mathrm{z}=-.96, p=0.34)$, the information of the dramatic text $(\mathrm{z}=-1.59, p=.11)$, the plot and action elements $(\mathrm{z}=-1.06, p=.29)$ and the Shadow Theatre elements ( $\mathrm{z}=-.56, p=.58$ ). It was observed that the average grading for the girls was higher $(M=34.21)$ for the task concerning the audio code than that of the boys $(M=24.09)(z=-$ $2.37, p=.02$ ). Finally, the total score of the scales for the overall evaluation of theatrical memory from the theatre codes point of view, does not present gender differences ( $\mathrm{z}=-1.70, p=.09)$. Therefore, no gender influence is inferred. 
The overall score of each one of the above seven recall and recognition tasks is positively and strongly related with the overall score of them. The correlation values fluctuate from .34 to .78 and are statistically important $(p=.00<.001)$. Also, the Cronbach $\alpha$ index for the 32 items that the seven tasks include, presented a value equal to .82 .

\section{Discussion}

The study aimed at the structure and the psychometric evaluation of seven individual categories of recall and recognition tasks, based on the exploitation of the theatre codes of Mike Kenny's "Boy with a suitcase" performance, translated by Xenia Kalogeropoulou (Kappa Theatre, Greece 20172019). Those tasks were addressed to $5^{\text {th }}$ Grade Primary School pupils and aimed to the quantitative evaluation of the young spectator's theatrical memory.

The criteria for the selection of the items that consist each task were the difficulty index of each item, its differentiation index and the evaluation of the expert judges, degree of agreement, concerning thematic content. Of the initial 62 elements to be evaluated, only 32 were eventually kept because they presented ideal values on an index level, thus denoting that they could come up to the expectations of the examined persons and could therefore contribute to the measure of the theatrical memory of the participants per each theatre code level. Especially, as far as the evaluation of their difficulty index is concerned, it fluctuated between 46-86, an ideal value for cases of triple choice answers (Aiken, 1994; Alexopoulos, 1998; Gregory, 1992). As for their differentiation index, this was more than .20 , an acceptable value according to analysis patterns for psychometric research (Alexopoulos, 1998). Finally, as for the expert judges' agreement degree, every item that was kept presented a high degree of agreement between the judges, an element that contributes to the structural validity of the items.

With the elements that were kept, seven categories were named/selected via inquiry factor analyses, seven categories of univariable evaluable tasks concerning a) the (actors') acting, b) the visual frame, c) the audio code, d) the lights, e) the dramatic text, f) the plot and action elements and g) the Shadow Theatre technique of the specific performance, with satisfactory reliability, internal coherence and conceptual structure validity. The first task

With the elements that were kept, seven categories were named/selected via inquiry factor analyses, seven categories of univariable evaluable tasks concerning a) the (actors') acting, b) the visual frame, $c$ ) the audio code, d) the lights, e) the dramatic text, $f$ ) the plot and action elements and $g$ ) the Shadow Theatre technique of the specific performance, with satisfactory reliability, internal coherence and conceptual structure validity that referred to the (actor's) acting, included items concerning spatial placement, kinesiology, vocals, mimicry and scenic interpretation in general. The second task, concerning the visual frame theatre code, included items about the stage, the scenic mechanisms and objects and costumes. The third task concerning the audio code, included items on the audio environment of the performance, such as live music, songs, musicians and sound effects. The forth task concerning the lights, 
included items about the function of the lights in that particular performance (focusing attention, the coloring of the stage, the creation of a certain atmosphere and so on) and its cooperation with the other codes (e.g. the visual frame). The fifth task concerning the information of the performance content, included items about the content of the dramatic text as this was interpreted by the actors on stage. The sixth task that concerned the plot and the action of the play, included items that were focusing on the content of climax scenes of the action, interchanges, reversals and conflicts. Finally, the seventh task concerning Shadow Theatre technique, consisted of items about the involvement of this specific technique in the development of the action, the boxed stories and the characters categories of tasks could support the validity and efficiency of a tool that measured the pupils' theatrical memory.

\section{Limitations and proposals for future research}

The basic limitation of the research originates from the non-probabilistic selection of the participants. Despite the fact that chi-square tests showed that the size of the sample used in the research was efficient/satisfactory, a sample originating from non-probabilistic types of sampling and especially representative of the population of $5^{\text {th }}$ Grade pupils would be desirable.

It is important that the research we are to develop after the pilot study, will focus on the exploration of the theatrical performance factors that are etched on the pupils' memory for a longer period, and will also give prominence to the theatre codes that create (and for what reason too) strong memories, thus facilitating the pedagogical role of theatre.

In the expectations of this research, we must also mention the highlighting of the individual elements that spectators recall and recognize and may be exploited for the overall evaluation of the pupils' theatrical memory based on the semiotic analysis of the performance and the reception theories.

\section{Acknowledgments}

We wish to express our gratitude to Associate Professor of Cognitive Psychology and Director of the Experimental Psychology Laboratory (NKUA), Dr. Petros Roussos, whose ideas and general contribution to our research were of great importance. The present research is being conducted by the authors of this article within the frame of the research program under the title "Theatrical memory of 5th Grade Primary school pupils" in the Department of Primary Education of the National and Kapodistrian University of Athens, Greece with Professor Theodore Grammatas being the Principal Investigator, Invitation EABM 34 "Support to researchers with emphasis on young researchers" MIS 5006824. 


\section{References}

Aiken, L. R. (1994). Psychological testing and assessment. Boston: Allyn Bacon.

Allen, M. J., \& Yen, W. M. (2002). Introduction to measurement theory. Long Grove, Illinois: Waveland Press.

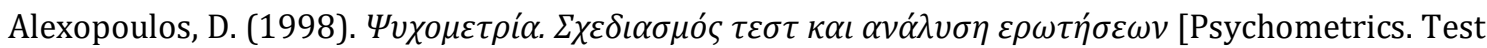
design and question analysis]. Athens: Ellinika Grammata.

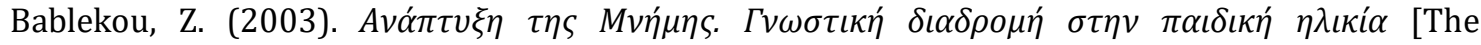
development of memory. Cognitive overview to childhood]. Athens: Typothito.

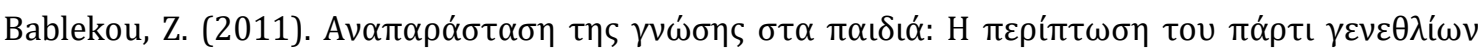
[Representation of knowledge in children: the birthday party case]. In K. Chryssafidis, \& E.

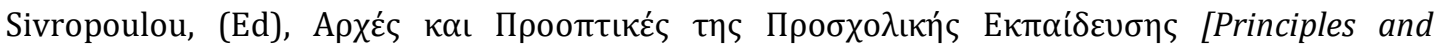
perspectives of early childhood education] (pp. 123-151). Thessaloniki: Kyriakides Bros Publications.

Balme, C. (2008). The Cambridge introduction to theatre studies. Cambridge: Cambridge University Press.

Biasutti, M., \& Frate, S. (2017). A validity and reliability study of the attitudes toward sustainable development scale. Environmental Education Research, 23(02), 214-230.

Carlson, M. (2003). The haunted stage: the theatre as memory machine. Ann Arbor, MI: University of Michigan Press.

Casey, E. (2000). Remembering a phenomenological study. Bloomington: Indiana University Press.

Clark, L. A., \& Watson, D. (1995). Constructing validity: basic issues in objective scale development. Psychological Assessment, 7(3), 309-319.

Cortina, J. M. (1993). What is coefficient alpha? an examination of theory and applications. Journal of Applied Psychology, (78), 98-104.

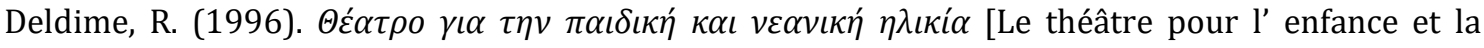
jeunesse]. Athens: Typothito.

DeVellis, R. F. (2003). Scale development: theory and application. Thousand Oaks, CA: Sage.

Elam, K. (2002). The semiotics of theatre and drama. London: Routledge.

Falotico, R., \& Quatto, P. (2015). Fleiss' kappa statistic without paradoxes. Quality \& Quantity, 49(2), 463-470.

Field, A. (2013). Discovering statistics using SPSS. London: SAGE. 


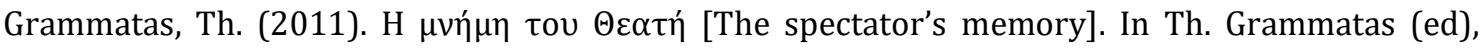

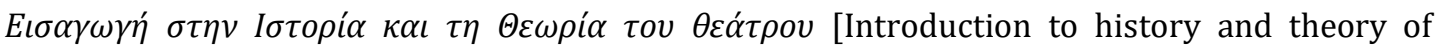
theatre] (pp. 173-195). Athens: Exantas.

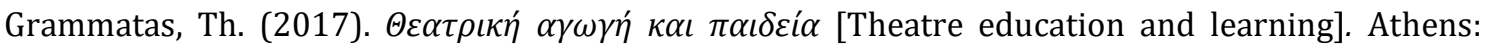
Diadrasi.

Gregory, R. J. (1992). Psychological testing. History principles and applications. Boston: Allyn Bacon.

Halbwachs, M. (1964). La memoire collective. Paris: Universitaires de France.

Hasher, L., \& Griffin, M. (1978). Reconstructive and reproductive processes in forgetting. Journal of Experimental Psychology: Human Learning and Memory, (4), 318-330.

Hinkin, T. R., Tracey, J. B., \& Enz, C. A. (1997). Scale contraction: developing reliable and valid measurement instruments. Journal of Hospitality \& Tourism Research, 21(1), 100-120.

Kline, P. (1999). A Handbook of psychological testing. London: Routledge.

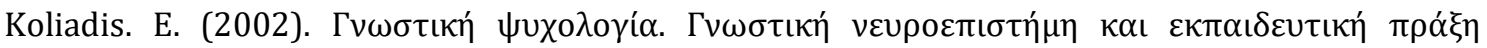
[Cognitive psychology. Cognitive neuroscience and educational action]. Athens: Ianos.

Lord, F. M., \& Novick, M. R. (1968). Statistical theories of mental test scores. Menlo Park, California: Addison-Wesley.

Novick, M. R. (1966). The axioms and principal results of classical test theory. Journal of Mathematical Psychology. 3(1), 1-18.

Nunnally, J. K., \& Bernstein, I. H. (1994). Psychometric theory. New York: McGraw-Hill.

Olick, J. (2007). The politics of regret: on collective memory and historical responsibility. New York: Routledge.

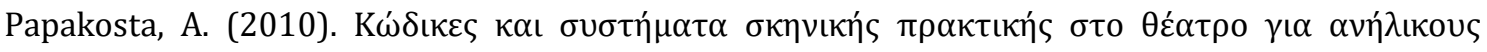
$\theta \varepsilon \alpha \tau \varepsilon \dot{s}$ [Codes and systems of theatre practice in the theatre for young spectators]. In Th.

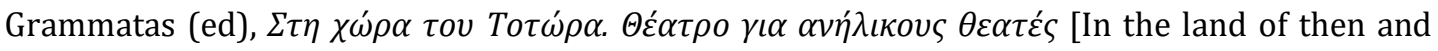
now. Theatre for young spectators] (pp. 361-410). Athens: Patakis.

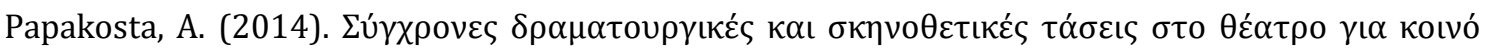
$\alpha v \eta \lambda i^{\kappa} \omega \nu v \varepsilon \varepsilon \alpha \omega \dot{\omega} v \sigma \tau \nu$ E $\lambda \lambda \alpha \dot{\alpha} \delta \alpha$ [Modern drama and direction trends in the theatre for young

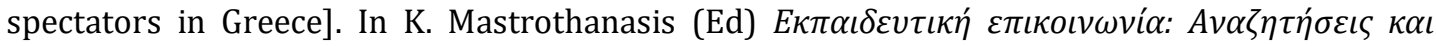

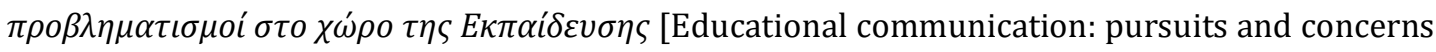
in the field of Education] (pp. 103-120). Thiva: “Pindar” Primary Education Teachers' Union.

Radstone, S., \& Schwarz, B. (Eds.) (2010). Memory: histories, theories, debates. New York: Fordham Univ Press. 


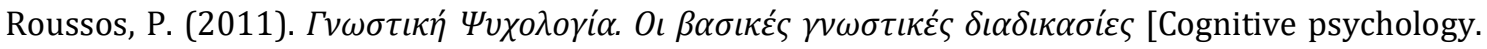

The basic cognitive processes]. Athens: Topos.

Schacter, D. (2001). The seven sins of memory. How the mind forgets and remembers. New York: Houghton Mifflin.

Siegler, R. (2013). Children's thinking: what develops? Hillsdale, NJ: Lawrence Erlbaum.

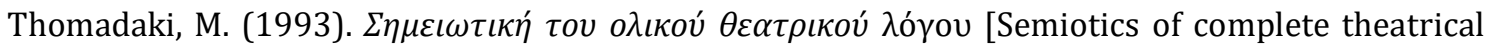
speech]. Athens: Domos.

Worthington, R. L., \& Whittaker, T. A. (2006). Scale development research: a content analysis and recommendations for best practices. The Counseling Psychologist, 34(6), 806-838.

\section{How to cite this paper:}

Papakosta, A. Mastrothanasis, K., Andreou, A. \& Blouti. I. (2020). Psychometric exploration of recall and identification tasks for the evaluation of the young spectators' theatrical memory. Journal of Literary Education, (3), pp. 176-196. doi: 10.7203/JLE.3.14835 


\section{Appendix}

\section{Indicative items of recall and recognition tasks per thematic unit}

\begin{tabular}{|c|c|}
\hline Thematic task & Item example \\
\hline Acting & $\begin{array}{l}\text { How did the mother speek before the boy got on board the bus? } \\
\text { a) Smiling, encouraging him and telling him jokes } \\
\text { b) Stammering, shaking and emotionally moved } \\
\text { c) Angrily and coldly }\end{array}$ \\
\hline Visual frame & Choose the correct description of the fixed scenery. \\
\hline Audio code & $\begin{array}{l}\text { What sounds were heard in the story of the stingy man? } \\
\text { a) Breathing and bubbles } \\
\text { b) Waves and birds } \\
\text { c) The wind and children's laughter }\end{array}$ \\
\hline Lights & $\begin{array}{l}\text { What happened every time the boy wrote a letter to his mother? } \\
\text { a) The moon lit up } \\
\text { b) It was dark } \\
\text { c) The lights went red }\end{array}$ \\
\hline Dramatic text & $\begin{array}{l}\text { What did the father tell the boy the moment they were abandoning their } \\
\text { hometown? } \\
\text { a) Look at the city for the last time } \\
\text { b) Never look back } \\
\text { c) See what disaster the war brings }\end{array}$ \\
\hline Plot/Action & $\begin{array}{l}\text { How did Krysia fall into the sea? } \\
\text { a) By mistake } \\
\text { b) She wanted to swim } \\
\text { c) The Captain pushed her }\end{array}$ \\
\hline Shadow Theatre & $\begin{array}{l}\text { The wolves in the boy's story appeared: } \\
\text { a) On a video on stage } \\
\text { b) As figures on the screen white sheet } \\
\text { c) As paintings }\end{array}$ \\
\hline
\end{tabular}

